PROBLEMS

OF MANAGEMENT IN THE $21^{\text {st }}$ CENTURY Vol. 12, No. 2, 2017

122 RECREATION OFFER AND COMPETENCES NEEDED FOR ITS DEVELOPMENT IN ACCOMMODATION ENTERPRISES OF KURZEME REGION IN LATVIA

\author{
Diāna Līduma, Ilze Grospiṇa \\ Liepaja University, Latvia \\ E-mail: diana_liduma@inbox.Iv, ilzegrospina@inbox.Iv \\ Zane Gusta \\ Zoovilla, Ltd., Grobina, Latvia \\ E-mail: z.timbra@googlemail.com
}

\begin{abstract}
Due to changes in tourism habits when planning development of tourism industry both on national and regional scale, the significance of recreation is highlighted. As a result, in tourism products made by guest accommodation enterprises the recreation offer is included more and more often.

Within the research it has been found out that in guest accommodation enterprises in Kurzeme, in addition to accommodation opportunities, the offer of catering dominates, but regarding recreation activitieswalking and relaxation in nature. The offer of bath-house treatment and cycling are more popular than SPA procedure and water attractions. The tendency of relaxation and entertainment event organization also increases in the companies. One realized imperfection of the offer is the tendency that in half of the regional accommodation enterprises the arrangement of relaxation activities has to be provided by the clients themselves.

The aim of the research is to find out the offer of the current recreation in guest accommodation enterprises in Kurzeme Region and the necessary employees' competences for its further development. Within the research a survey of 32 managers of guest accommodation enterprises in Kurzeme Region was carried out. The outcomes of the research reveal that additional services to accommodation are offered by $55 \%$ guest accommodation enterprises of Kurzeme. However, in 53.1\% cases the clients, staying at a guest accommodation enterprise in Kurzeme Region, have to provide arrangement of relaxation activities themselves. Only one fifth (21.9\%) of the companies provide it involving a specialist working for the company. Complex recreation programmes are offered by $9.7 \%$, but separate recreation activities by 29\% guest accommodation enterprises. Managers of guest accommodation enterprises in Kurzeme are aware of the potential in sports recreation events and relaxation activity organization. The outcomes of the research showed that the main competences necessary for the employees of guest accommodation enterprises, according to the managers of the companies, are language skills and the ability to make decisions and solve problem-situations. In 15.6\% of the enterprises a manager for relaxation arrangements would be needed right now.
\end{abstract}

Keywords: recreation offer, recreation activities, guest accommodation, specialists of recreation, competences, survey.

\title{
Introduction
}

The modern rapid pace of time has affected inhabitants', including tourists, habits of leisure time spending. In the social and work environment, encountering various negative chemicals, biological and physical factors, people have health problems and the work efficiency decreases. The impact of these factors has promoted both development of recreation services in 
general and application of tourists' attraction. As a result, tourism services and recreation activities are created in the tourism products' mutual correlation. This fact entails a demand for new

PROBLEMS

OF MANAGEMENT

IN THE $21^{\text {st }}$ CENTURY

Vol. 12, No. 2, 2017 competences in tourism enterprises. Recreation management becomes topical. Development of the recreation offer is included in a range of tourism industry's planning documents both on a national, regional and urban scale. The significance of recreation tourism on a national scale of Latvia is confirmed by the Latvian Association of Resort Cities founded on April 28, 2008 and Latvian Health Tourism Cluster founded in March, 2012 with the goal to "promote a sustainable collaboration with companies and education and knowledge dissemination organizations working in health tourism of Latvia, thus increasing their competitiveness in health care and health tourism, and promoting the increase of the foreign travellers' total expenses in Latvia and development of products with the high added value" (Latvijas kūrortpilsētu asociācija, 2013). Already historically in Latvia the status of kurortology belonged to such cities of Vidzeme as Jūrmala, Baldone, Ogre, Saulkrasti, but in Kurzeme Region - to Liepaja. Also from the future perspective the increase of recreation role in the region of Courland can be seen. It is confirmed by both Decision No 64 of Liepāja City Council on February 19, 2015 "About Development Concept of Liepāja's Resort for 2015-2020" with the goal to obtain the status of the resort zone for a part of Liepāja City municipal territory (Liepājas pilsētas dome, 2015), and "Sustainable Development Strategy of Ventspils Region until 2030," where tourism and recreation have been marked as the specialization direction of Ventspils Region (Dadzis, 2017). Also, in the development programme of Kuldīga Region for 2014-2020 tourism has been mentioned as the economic specialization direction, highlighting that "the region has got diverse tourism offers - different natural, cultural, culture-historical, recreational tourism, as well as medical and SPA tourism services and products are available" (Kuldiggas novada dome, 2013, 16). The mentioned facts in the planning documents of the regional cities and districts confirm the potential of the industry in Kurzeme Region. This motivates the tourism entrepreneurs to develop the offer in the recreation field and requires provision of professional workforce in tourism enterprises. Annually a positive tendency of the increase of hotels and other tourism accommodation can be noticed - according to the CSB (Central Statistical Bureau of Latvia Republic) data in 2016 they are 120 in total in Kurzeme (compared to 2015 when there were 89 hotels and other tourism accommodation, but in 2014 - 81) (CSP, Viesnīcas un citas tūristu mìtnes..., 2017). The number of serviced people also increases in Kurzeme - 239,716 people which is by 41,017 more than in 2015 (198,699 people) (CSP, Viesnīcas un citas tūristu mìtnes..., 2017), and according to the CSB data the purpose of $47.5 \%$ foreign travellers has been just relaxation (CSP, Ārvalstu vairākdienu celotāju..., 2017). The complex tourism services in Latvia have been received by 34,774foreign tourists and 38,823 domestic travellers (CSP, Tūrisma komersantu darbības raksturojošie rādītāji, 2017). However, to assess precisely development of recreation tourism, a common awareness of the term application is missing in the country in order to record the statistics of both tourism business and industry. Currently the term of recreation enterprise has not been defined precisely in Latvia. Recreation services as additional services are mostly provided by the enterprises dealing with guest accommodation. Taking into account the increase of the term's topicality, the explanation of the term "recreation" and understanding of "recreation tourism" cause a theoretical discussion in the context of different paradigms.

Science of etymology has discovered that the word recreation dates back to 1400 and has originated from the Latin word "recreation," which possesses several meanings such as health recovery, create again, rebirth and encouragement (Online Etimology Dictionary, 2017). Taking into account the historical origin of the word recreation and its long-term application, the modern understanding of recreation is varied. It has been confirmed by the verities of such researchers as John Tribe, Daniel D. McLean, Amy R. Hurd, Marion Clawson and Jack L. Knetsch.

Collating the definitions on recreation provided by the professor Daniel McLean from Nevada University and the professor Amy Hurd from Illinois University it can be concluded that recreation are activities of different kind together with the physical and mental involvement in order to improve the health condition, integrate into the society, obtain a new experience and 
Diāna LİDUMA, Ilze GROSPIN̦A, Zane GUSTA. Recreation offer and competences needed for its development in accommodation enterprises of Kurzeme region in Latvia

PROBLEMS

OF MANAGEMENT IN THE $21^{\text {st }}$ CENTURY Vol. 12, No. 2, 2017

124

knowledge outside the permanent place of residence (McLean, Hurd, 2011, 63). Taking into account that, a link can be created with the tourism field, even though in the authors' opinion it cannot be directly noticed. Also the economist from the USA agriculture, governmental person, expert on sustainable natural resource consumption Marion Clawson and the specialist of the environmental economics Jack L. Knetsch in the book "Economics of Outdoor Recreation" explain that recreation is closely related to relaxation including all kinds of activities or planned idleness including housework, cooking, embroidery and other daily activities (Clawson, Knetsch, 2011, 6-7), without showing a direct relation between recreation and tourism.

It can be only noticed when analysing more profoundly the three recreation paradigms by the authors Marion Clawson and Jack L. Knetsch: the paradigm of outdoor recreation, the paradigm of natural resources and the paradigm of recreation activities. The outdoor recreation is relaxation in nature, for example, walking in a forest without natural resource application, unlike the paradigm of natural resources which is based on application of natural healing resources for people's health improvement. The paradigm of recreation activities is different organized activities in the urbanized environment such as group activities, games, orienteering, fishing and hiking (Clawson, Knetsch, 2011, 6-7). The above mentioned authors' opinions differ from explanation of the three recreation paradigms provided by the English tourism professor John Tribe, likewise dividing the paradigms between the home-based recreation and recreation away from home, but dividing separately the paradigm of travel and tourism recreation, thus showing us a possibility of close connection between tourism and recreation. J. Tribe describes the home-based paradigm, similarly to the above mentioned researchers, as relaxation in the permanent place of residence, listening to music, watching TV and reading books. The recreation away from home is described as activities of different kind outside the permanent place of residence, for example, sports activities, attending events, hobbies, going to restaurants and gambling. In its turn, the paradigm of travel and tourism is described as activities of travelling, accommodation and recreation at a particularly chosen destination (Tribe, 2012, 4).

The division of recreation types in the Tourism and Hospitality Explanatory Dictionary (Bērzina, 2008) issued by the Ministry of Economics of Latvia Republic is similar to Marion Clawson and Jack L. Knetsch authors' work, but the "English-Latvian Tourism Explanatory Dictionary" by Ronalds Pētersons and Enārs Plinta explain the meaning of the "recreation tourism" as a synonym to the world relaxation, including in it the traveller's physical and mental health recovery, applying natural and artificial convalescence resources and dividing them into two sub-groups: the healing tourism paradigm and relaxation tourism paradigm. The relaxation tourism paradigm includes different kinds of trips with a goal to relax, renew the physical and mental powers, relax from the daily routine, applying the charm of forests, waters, relief and landscape, as a result the human health is strengthened in general. But the healing tourism paradigm is defined as travelling with a goal to improve health, applying the natural healing resources (Pētersons, Plinta, 2002, 185).

Similar interpretations of the term also exist in the Tourism Law in force in Latvia, applying the terms: "recreation tourism" - "a type of tourism whose goal is to renew the human physical and mental potential, applying rationally the natural and artificial relaxation and convalescence resources" (Latvijas Republikas Saeima, 1999); "health tourism"- a kind of tourism whose goal is improvement, prophylaxis, treatment and rehabilitation of the body's general condition and wellbeing, applying also the natural healing resources" (Latvijas Republikas Saeima, 1999).

The theoretical analysis proves there is not a single universal recreation and recreation tourism paradigm on which all specialists, professors, scientists and practitioners in the area would rely on. The lack of a common universally applicable theoretical platform encumbers essentially not only the development of the recreation area, but also the practical work, including the assessment possibilities of the situation. The theoretical analysis also confirms different points of view about the division of recreation activities. The types of recreation are divided into groups depending on their characteristics: functions, recreational action character, venue 
and time, necessary gear, number of recreants and other features. From the Latvian author K. Bērzina's (2008) point of view in the division of recreation types there can be distinguished: active recreations, passive recreations, healing recreations, indoor recreations, outdoor recreations, sports recreations and groups of leisure time activities. Also, the selection of the venue has got an essential meaning for action implementation. The recreation venue includes home, public institutions, parks, relaxation zones, any place in wildlife that is used for human relaxation. If the recreation place attracts tourists, then simultaneously they are also used as tourism places or objects (Bērzinia, 2008).

Studying understanding of recreation and recreation tourism in the context of different paradigms according to both different authors' work and the Tourism Law in force in Latvia and dictionaries on tourism, the diversity of recreation essence and characteristic features are revealed. In conclusion, in the practice of tourism enterprises in regions of Latvia the divisional amalgamation of recreation types by Marion Clawson, Jack L. Knetsch and the Tourism and Hospitality Explanatory Dictionary by the Ministry of Economics of Latvia Republic is applied, which envisages the development and introduction of the active, passive, healing, natural, sports and leisure recreation kind activities in the tourism product appropriate for both indoors and outdoors, applying the natural healing and artificially made resources in order to renew the human being's physical and mental condition. In the recreation tourism context, the most topical is the fact that the tourist decides to implement it in the chosen destination, combining the trip with accommodation and recreation activities in one place. Taking into consideration that in tourism different industrial segments are related, also the recreation opportunities are provided not only by tourism, but also e.g. relaxation organizations, health and sports enterprises. On the basis of the fact that the tourist's stay at the destination is mostly provided by the enterprises dealing with the guest accommodation, the goal of the empiric research is to find out the current recreation offer in guest accommodation enterprises in Kurzeme Region and the necessary employees' competences for further development.

\section{Methodology of Research}

\section{General Background of Research}

According to the theoretical aspect about the variety of recreation offer, it can be concluded there are no distinctly divided recreation activities just in tourism field. Basically, the recreation offer (active, passive, healing, natural, sports or leisure type activities) included in the tourism product has to be guaranteed to the guest just at the chosen tourism destination. It creates differences of the recreation offer available in tourism in various regions. Due to the tourism industry development planning that promotes the significance of recreation in the tourism offer both on the answers to the questions: what kind of recreation activities dominate in the recreation offer of the guest accommodation enterprises in Kurzeme Region? What kind of tourism offer do the managers of guest accommodation enterprises see the potential to in the future? What kind of specialists' competences are necessary for guest accommodation in enterprises, for the development of the recreation offer?

For data acquisition on the offer of the existing recreation services in guest accommodation enterprises in Kurzeme Region and for the employees' competences necessary for its development a survey of the managers of guest accommodation enterprises in Kurzeme Region was carried out within the research. The survey was carried out from September 10 to November 7,2017 . The questionnaire of the survey was made online on docs.google.com/forms, sending out the link of the questionnaire to the respondents' email addresses. In total, the questionnaire was sent to 65 guest accommodation enterprises with recreation trend of Kurzeme Region. 7 email addresses were returned as non-existent, which means the questionnaire has reached 54 regional guest accommodation enterprises. 
Diāna LİDUMA, Ilze GROSPIN̦A, Zane GUSTA. Recreation offer and competences needed for its development in accommodation enterprises of Kurzeme region in Latvia

PROBLEMS

OF MANAGEMENT

IN THE $21^{\text {st }}$ CENTURY Vol. 12 , No. 2, 2017

126

Thirty-two managers of the guest accommodation enterprises have replied. By the type of the accommodation enterprise just the "holiday homes" (40.6\%), "guest homes" (28.1\%) and "hotels" (18.8\%) make the biggest proportion out of all surveyed enterprises, which also actually structure the offer of recreation services in guest accommodation in enterprises in the region. Replies have also been sent by the managers of camping (15.6\%), country house (12.5\%), as well as other companies of accommodation type (e.g. hostels, apartments and tent places). $56.3 \%$ of the surveyed enterprises have already worked in the guest accommodation business for a long time ( $28.1 \%$ have been engaged in guest accommodation from $6-10$ years, $18.8 \%$ from 11-15 years and 9.4\% more than 15 years. Thus, it can be assumed that the obtained data confirm the outcomes of the long-term experience in this field. By the respondents' division $34.4 \%$ of guest accommodation companies have worked from $1-5$ years and $9.4 \%$ have started their business during the last year, which still confirms the attraction of the business in Kurzeme Region. Most probably the issue of professional specialists' attraction in the industry could be topical just to these $43.8 \%$ new enterprises.

\section{Sample of Research}

Taking into account that according to the SCB data in Kurzeme Region in early 2017 there have worked 120 hotels and other tourism dwellings (CSP, Viesnīcas un citas tūristu mitnes..., 2017), in the research selection in compliance with the set goal - characterization of recreations offer's tendencies in accommodation of Kurzeme Region, excluding the offers in medical tourism - in medical and rehabilitation service provision, according to the data provided by the Kurzeme Region Tourism Information Centre 65 guest accommodation enterprises have been selected and included, or $54 \%$ of all accommodation enterprises in the region.

\section{Instrument and Procedures}

Within the research a questionnaire with 12 questions has been developed (including demographic issues of 3 companies), with whose help both the information on the types of relaxation activity organization, the current and planned offer in the guest accommodation companies, and managers' perspective opinion on development of individual tourism types and attitude to specialists' training for recreation and relaxation organizations in tourism in Kurzeme Region was found out. It should be noted that the necessary competences for professional work implementation in both the "Recreation Specialist," and "Manager of Tourism and Relaxation Organization" professions in Latvia Republic are determined by the "Regulations about Profession Classification, appropriate principle tasks and basic requirements for the qualification" (Ministru kabinets, 2017). The mentioned document has been used in order to offer the managers of guest accommodation enterprises in the survey precise specialists' competencies currently stated within the law, comparing them with the ones mentioned by the managers for the current needs in the enterprises.

The chosen time for survey from September 2017 coincides with the period of the tourism closing season in Latvia, so that for the respondents, when answering the questions, it would be easier to assess both the provided offer within the last season and employees' competence in its performance.

\section{Data Analysis}

Statistical data processing methods (descriptive statistics) and Microsoft Excel application were used to process the quantitative data of research. The obtained data is displayed in the tables and graphs by means of diagrams. 


\section{Results of Research}

Carrying out an empiric research on the current recreation offer in guest accommodation dwellings in Kurzeme Region and surveying 32 managers of guest accommodation enterprises in Kurzeme Region, an opinion about the current tendencies, potential development and the necessary employees' competences for its management have been obtained.

\section{Analysis of Kurzeme Guest Accommodation Enterprises' Offer}

In terms of the accommodation offer in Kurzeme $41.9 \%$ of the surveyed enterprises offer catering services, but $45.2 \%$ of the companies provide only accommodation possibilities. In $29 \%$ of guest accommodation enterprises separate recreation activities are also available, but complex recreation programmes are offered only by $9.7 \%$. Arrangement of entertainment and relaxation events is offered by $32.3 \%$, but relaxation infrastructure that clients can use by their own discretion $-38.7 \%$ of guest accommodation enterprises (Figure 1).

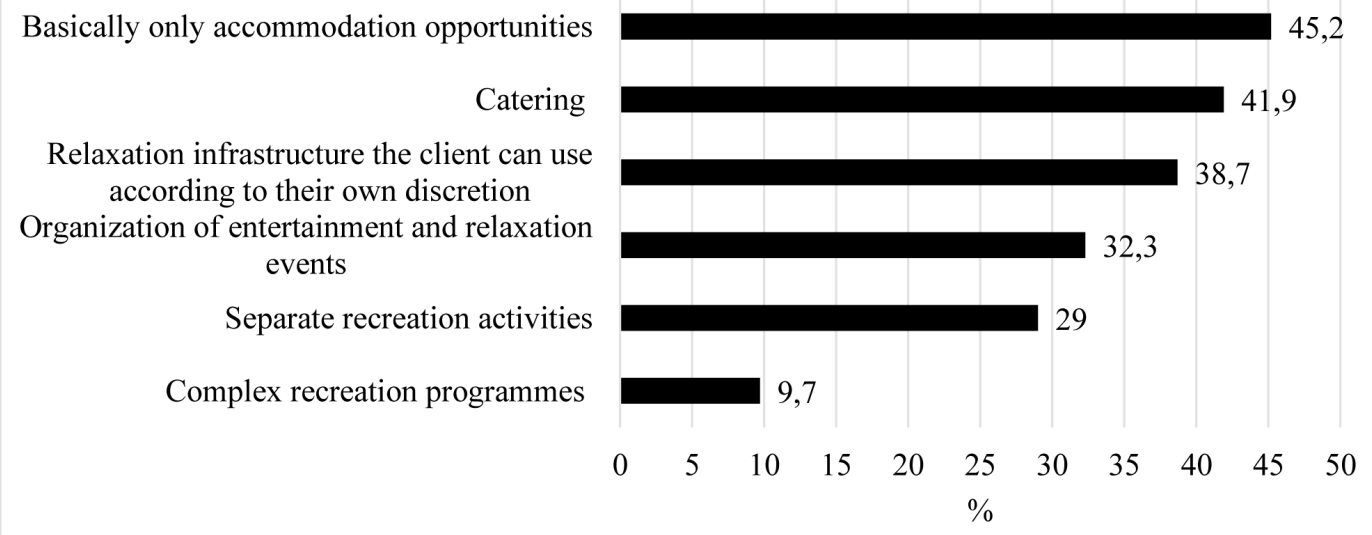

Figure 1: Accommodation offer in Kurzeme $(n=32), \%$.

Regarding recreation activities: $89.7 \%$ of guest accommodation enterprises in Kurzeme offer walks and relaxation in nature (on the seaside, in parks and along natural trails), $62.1 \%$ -cycling and bath-house treatment. There are options for Nordic walking (41.4\%) and boating (31\%), as well as organized creative activities (master-classes, self-development, etc.) - $31 \%$ and for sports activities (curative exercise, yoga etc.) $-24.1 \%$. Water attractions are offered by only $13.8 \%$ enterprises, but SPA treatment (mostly massages, aroma therapy and beauty care) is offered by only $10.3 \%$ of guest accommodation enterprises in Kurzeme (Figure 2). 
Diāna LİDUMA, Ilze GROSPIN̦A, Zane GUSTA. Recreation offer and competences needed for its development in accommodation enterprises of Kurzeme region in Latvia

OF MA

NAGEMENT

IN THE $21^{\text {st }}$ CENTURY

Vol. 12, No. 2, 2017
Walking and relaxation in nature Cycling Bath-house treatment Nordic walking Boating Creative activities Sports activities Horse riding Water attractions/ swimming-pool SPA treatment

Weight correction programmes Addiction treatment

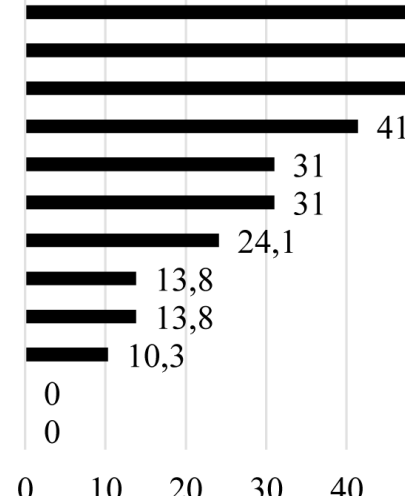

89,7

62,1 62,1
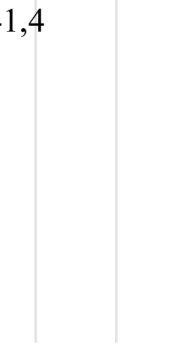

$\begin{array}{lllll}60 & 70 & 80 & 90 & 100\end{array}$

Figure 2: Available recreation activities in Kurzeme accommodation $(n=32)$, \%.

In $53.1 \%$ cases, while staying at a guest accommodation enterprise in Kurzeme, clients provide arrangement of relaxation activities themselves, but in $21.9 \%$ it is provided by a specialist employed by the company. In $15.6 \%$ cases a partner/outsourcing provider is hired for relaxation and recreation activity provision in a guest accommodation enterprise (Figure 3).

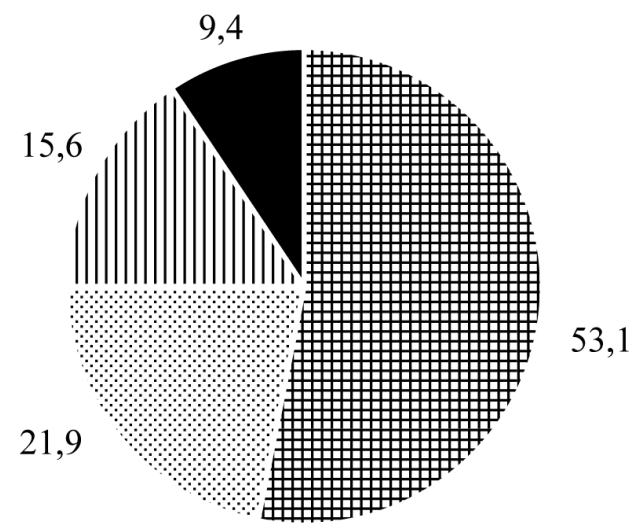

${ }^{*}$ Clients provide themselves

Provided by a specialist working for the enterprise

\author{
" A partner/outsourcing \\ provider is attracted for \\ relaxation and recreation \\ activity provision \\ - Not offered
}

Figure 3: Available recreation activities in Kurzeme accommodation $(n=32)$, \%.

During a year up to three-year time $65.6 \%$ of guest accommodation enterprises in Kurzeme Region are planning to develop new recreation offers, but $68.8 \%$ invest into the existing service development. $18.8 \%$ of the surveyed business managers are planning to attract new specialists for relaxation and recreation management. $12.5 \%$ are planning to introduce new healing and health improvement services. $15.6 \%$ of guest accommodation enterprises in Kurzeme Region are not planning any changes in the current offer (Figure 4). 
Invest into further development of the existing service

Develop new relaxation offers

Attract new specialists for relaxation organization and recreation management Offer new healing and health improvement services

Changes are not planned in the current offer

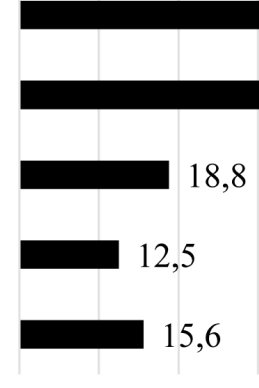

$\mid \begin{aligned} & \text { PROBLEMS } \\ & \text { OF MANAGEMENT } \\ & \text { IN THE 21 } 1^{\text {st }} \text { CENTURY } \\ & \text { Vol. 12, No. 2, } 2017\end{aligned}$

68,8

65,6

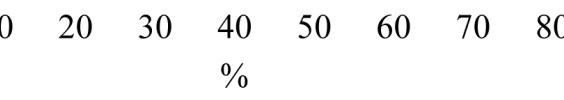

Figure 4: Planned development for accommodation offer during 1-3 year time $(n=32), \%$.

Pointing at the areas for tourism development in Kurzeme Region in future, the managers of accommodation enterprises have noticed more perspectives in sports recreation events and relaxation activity organization than SPA treatments (Figure 5).

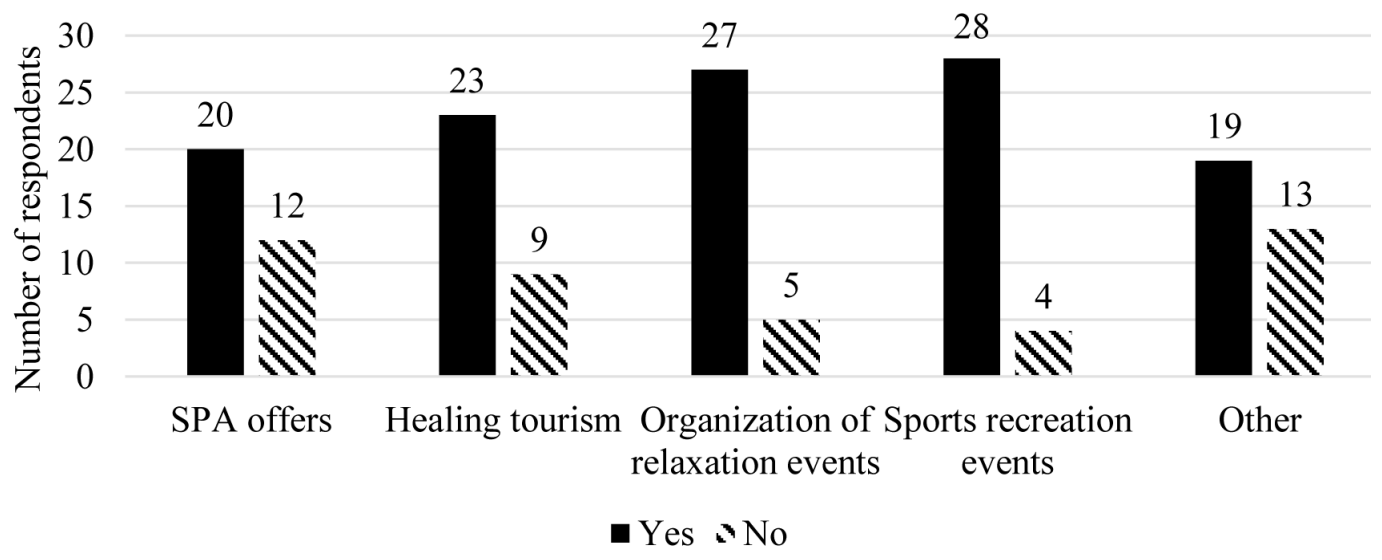

\section{Figure 5: Areas in which future perspectives are seen in tourism development in Kurzeme Region $(n=32)$, number.}

Need for Specialists' Training in Recreation and Relaxation Organization

The outcomes of the research confirm that just the training of tourism and relaxation managers are necessary on both the higher professional $(43.8 \%)$ and secondary professional (25\%) education level. The business managers' opinion shows that training of recreation management specialists with higher professional and recreation specialists with secondary professional education are less needed (respectively 12.5\%). 6.3\% have replied that training of the mentioned specialists is not needed (Figure 6). 
Diāna LİDUMA, Ilze GROSPIN̦A, Zane GUSTA. Recreation offer and competences needed for its development in accommodation enterprises of Kurzeme region in Latvia

PROBLEMS

OF MANAGEMENT IN THE $21^{\text {st }}$ CENTURY Vol. 12, No. 2, 2017

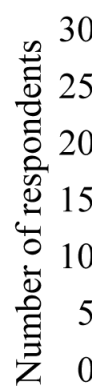

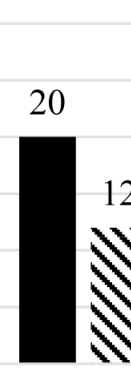

SPA offers

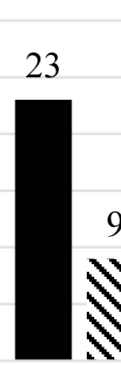

Healing tourism
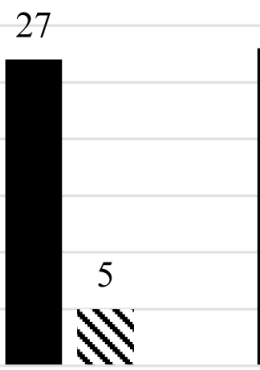

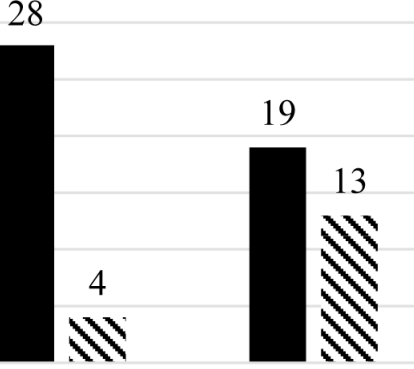

Other relaxation events events

-Yes No

Figure 6: Opinion about specialists' training in recreation and relaxation organization in tourism in Kurzeme Region $(n=32)$, \%.

Assessment of Knowledge and Competences Needed for Business Employees from the Business Managers' Point of View in Kurzeme Region Guest Accommodation Enterprises

Regarding the competences, today the employees of guest accommodation enterprises really need the knowledge of the state language and foreign languages, ability to solve problem-situations and make decisions within their competence taking responsibility for the consequences (Table 1).

Table 1. Assessment of communication and collaboration skills needed for the business employees from the business managers' point of view in Kurzeme Region accommodation enterprises $(n=32)$, number.

\begin{tabular}{|c|c|c|c|c|c|}
\hline & $\begin{array}{l}\text { Not needed } \\
\text { at all }\end{array}$ & $\begin{array}{l}\text { Not } \\
\text { needed }\end{array}$ & $\begin{array}{l}\text { Partly } \\
\text { needed }\end{array}$ & Needed & $\begin{array}{l}\text { Really } \\
\text { needed }\end{array}$ \\
\hline $\begin{array}{l}\text { Ability to apply information for the sake of own work } \\
\text { improvement. }\end{array}$ & 3 & 4 & 9 & 10 & 6 \\
\hline $\begin{array}{l}\text { Ability to maintain the link and cooperate with national } \\
\text { and municipal institutions in recreation event organiza- } \\
\text { tion. }\end{array}$ & 3 & 4 & 9 & 12 & 4 \\
\hline $\begin{array}{l}\text { Ability to work in team, delegate and coordinate respon- } \\
\text { sibilities. }\end{array}$ & 3 & 8 & 5 & 10 & 6 \\
\hline Ability to solve problem-situations. & 3 & 7 & 4 & 7 & 11 \\
\hline $\begin{array}{l}\text { Ability to make decisions within own competence and be } \\
\text { responsible for the consequences. }\end{array}$ & 3 & 8 & 2 & 9 & 10 \\
\hline $\begin{array}{l}\text { Ability to apply and act in compliance with the require- } \\
\text { ments of regulations and principles of work ethics. }\end{array}$ & 5 & 7 & 6 & 7 & 7 \\
\hline $\begin{array}{l}\text { Ability to communicate in the state language and at least } \\
\text { two foreign languages. }\end{array}$ & 2 & 4 & 5 & 9 & 9 \\
\hline
\end{tabular}

The managers of guest accommodation enterprises in Kurzeme appreciate the employees" "ability to apply information for their work improvement" and "ability to maintain the link and cooperate with the national/ municipal institutions in recreation activity organization." Mixed opinions are about such employees' competence as the "ability to apply and act in compliance with the requirements of regulations and work ethics principles." The significance of 
knowledge in marketing, public relations and project management is appreciated. The employees' knowledge in international relations is less topical. There are different opinions about the

PROBLEMS

OF MANAGEMENT

IN THE $21^{\text {st }}$ CENTURY

Vol. 12, No. 2, 2017 need of knowledge in finance, quality and strategic management field (Table 2).

Table 2. Assessment of the knowledge in management area needed for the business employees from the managers' point of view in Kurzeme Region accommodation enterprises $(n=32)$, number.

\begin{tabular}{lllllll}
\hline & $\begin{array}{l}\text { Not needed } \\
\text { at all }\end{array}$ & $\begin{array}{l}\text { Not } \\
\text { needed }\end{array}$ & Partly needed & Needed & Really needed \\
\hline Ability to orientate in international relations & 4 & 10 & 5 & 8 & 5 \\
\hline Knowledge in marketing and public relations & 3 & 4 & 9 & 10 & 6 \\
\hline Knowledge in finance management & 3 & 9 & 6 & 9 & 5 \\
\hline Knowledge in strategic planning & 3 & 7 & 8 & 8 & 6 \\
\hline Knowledge in project management & 3 & 4 & 9 & 10 & 6 \\
\hline Knowledge in quality management & 3 & 7 & 9 & 10 & 3 \\
\hline
\end{tabular}

Comparing the managers' opinion of guest accommodation enterprises in Kurzeme Region with the principle tasks and qualification requirements stated for the recreation specialist's profession in Latvia (Ministru kabinets, 2017), the obtained outcomes of the research confirm that the managers of the guest accommodation enterprises do not see the need for such employees' competences as the "ability to motivate people to get involved in recreation activities," "ability to provide advice on a healthy lifestyle implementation" and "ability to provide advice and practical help in recreation tools, gear and necessary equipment selection." (Table 3).

Table 3. Assessment of the special skills needed for the business employees in recreation area from the managers' point of view in Kurzeme Region accommodation enterprises $(n=32)$, number.

\begin{tabular}{llllll}
\hline & $\begin{array}{l}\text { Not needed } \\
\text { at all }\end{array}$ & Not needed & $\begin{array}{l}\text { Partly } \\
\text { needed }\end{array}$ & Needed $\begin{array}{l}\text { Really } \\
\text { needed }\end{array}$ \\
\hline $\begin{array}{l}\text { Ability to orientate in recreation resources and apply } \\
\text { them. }\end{array}$ & 4 & 10 & 10 & 6 & 2 \\
\hline $\begin{array}{l}\text { Development and management of recreation routes and } \\
\text { infrastructure projects, events and programmes } \\
\text { (appropriate for the target group) }\end{array}$ & 2 & 10 & 7 & 10 & 3 \\
\hline $\begin{array}{l}\text { Ability to motivate people to get involved in recreation } \\
\text { activities. }\end{array}$ & 3 & 11 & 9 & 6 & 3 \\
\hline $\begin{array}{l}\text { Ability to provide advice and practical help in recreation } \\
\text { tools, gear and necessary equipment selection. }\end{array}$ & 3 & 11 & 7 & 9 & 2 \\
\hline $\begin{array}{l}\text { Ability to provide advice on a healthy lifestyle implemen- } \\
\text { tation. }\end{array}$ & 2 & 12 & 6 & 8 & 4 \\
\hline $\begin{array}{l}\text { Ability to treat people, natural resources and the envi- } \\
\text { ronment in a gentle way, applying recreation activities. }\end{array}$ & 1 & 12 & 4 & 10 & 5 \\
\hline $\begin{array}{l}\text { Ability to approbate innovative technologies applying } \\
\text { means of recreation. }\end{array}$ & 2 & 8 & 11 & 9 & 2 \\
\hline
\end{tabular}

The employees' ability "to orientate in recreation resources and apply them," development and management of recreation routes and infrastructure projects, events and programmes have been assessed as partly needed. The opinions regarding the significance of the compe- 
Diāna LİDUMA, Ilze GROSPIN̦A, Zane GUSTA. Recreation offer and competences needed for its development in accommodation enterprises of Kurzeme region in Latvia

PROBLEMS

OF MANAGEMENT IN THE $21^{\text {st }}$ CENTURY Vol. 12, No. 2, 2017

132 environment in a gentle way applying recreation activities," saying that "it is not necessary" and the same, assessing it as both "not needed," and "really needed."

\section{Discussion}

The offer of recreation services in Kurzeme Region is basically formed by guest houses, holiday homes and separate hotels that have been working in the tourism business for more than 6 years. $45.2 \%$ of the enterprises provide only accommodation opportunities. The most popular additional offer to accommodation possibilities in guest accommodation dwelling in Kurzeme is catering provision (41.9\%). Regarding recreation activities, the enterprises of Kurzeme Region mostly offer walking and relaxation in nature $(89.7 \%)$, cycling and bath-house treatment (62.1\%). Taking into account that Nordic walking (41.4\%), boating (31\%), organized creative activities and sports activities (24.1\%) are possible, and referring to the theoretically analysed recreation paradigms by the authors Marion Clawson and Jack L. Knetsch (Clawson, Knetsch, 2011, 6-7), it can be concluded that the paradigm recreation away from home dominates in Kurzeme Region, but according to Ronalds Pētersons and Enārs Plits' given explanation on the division of recreation tourism in the recreation tourism offer of Kurzeme Region, the emphasis can be noticed just on the relaxation tourism paradigm. The widest range of offers is available in the companies working for 11-15 years. Individual recreation activities are available in $29 \%$ of the enterprises, but complex recreation programmes are offered only by $9.7 \%$. SPA treatments are available in $10.3 \%$ of guest accommodation companies in Kurzeme, and these companies have worked no longer than for 6 years. A diverse SPA treatment - massages, homeopathy, aroma therapy, Ayurveda and beauty care services are provided only by the companies that have already worked for 11-15 years. In its turn, bath-house treatments are available in both newly created companies and in companies that have been working in guest accommodation for a long time in Kurzeme.

About $10 \%$ of guest accommodation companies (basically holiday homes) have started their work recently, which still confirms the attraction of the business in Kurzeme Region. The offer of the newly established guest accommodation enterprises is diverse, as both accommodation opportunities and separated recreation activities and complex recreation programmes are offered, as well as arrangement of relaxation and entertainment events, catering services and relaxation infrastructure that the clients can use according to their own discretion. In the surveyed guest accommodation enterprises, which have started their work during the last year, SPA treatments are not offered. A partner/ outsourcing provider is invited for the offered relaxation and recreation activity provision, but catering and entertainment organization is provided by a specialist working for the company.

The research confirms a common tendency that in most (38.7\%) of the guest accommodation enterprises in Kurzeme the relaxation infrastructure is available that can be used according to the clients' own discretion. One fifth (21.9\%) of the guest accommodation dwellings in Kurzeme Region provide relaxation organization in their company by the specialists' help working for their company, $15.6 \%$ use partners' attraction. This shows that for about $40 \%$ of guest accommodation enterprises in Kurzeme Region the application of recreation and relaxation organization specialists is topical, including also the cases when the recreation and relaxation organization specialists can prove themselves as outsourcing providers for guest accommodation enterprises. However, $53.1 \%$ of cases the clients have to provide themselves the arrangement of relaxation while staying at a guest accommodation enterprise in Kurzeme. It means the client is free to choose the type of relaxation, but at the same time the specialists' advice on the most suitable recreation types in compliance with the resources available at the tourism destination is not received. Taking into account the variety of recreation activities, just a competent specialist can be the one who can recommend the most suitable choice to the holidaymakers. 
Positive is the fact that $65.5 \%$ of guest accommodation enterprises in Kurzeme Region in their development, regardless the years worked in the industry, are planning to develop new relaxation offers during one to three year time and $68.8 \%$ are planning to invest in the development of the current services. This can determine the demand for specialists' competences in the industry in future. The business managers' opinions confirm that sports recreation events and relaxation activity organization have prospects. The research has found out that $12.5 \%$ are planning to offer new healing and health improvement services. Basically, they are the guest accommodation enterprises that have been working for 6 years or more. $15.6 \%$ are not planning any changes in the current offer.

Nearly fifth of the surveyed managers (18.8\%) of the guest accommodation enterprises are planning to attract new specialists for relaxation and recreation management. They are both the companies that have already been working for 6-10 years and are planning development of new offers, and 1-5 year-old accommodation companies which are planning to invest in the development of the current offer. Regarding the education level, managers' training for tourism and relaxation organizations is necessary with both higher professional and secondary professional education. Assessing the specialists' attraction in their companies right now - $15.6 \%$ have marked the need for a manager organizing relaxation, but $6.3 \%$ for a recreation specialist and $3.1 \%$ for a manager of recreation events and programmes. The business managers who are not planning any changes in their current offer mention they do not need a specialist in the above mentioned fields. Talking about the specialists' insufficiency in the guest accommodation enterprise, the business managers have mentioned: guides, maids, bath-house masters, waiters and chefs, as well as lack of responsible maintenance workers. Regarding competences, right now the employees of accommodation enterprises really need knowledge of languages, ability to solve problem-situations and make decisions. Business managers mention the employees' ability to maintain the link and cooperate with governmental/municipal institutions during activity organization as necessary, as well as knowledge in marketing, public relations and project management. Mostly, the necessity for such knowledge, also the employees' ability to solve problem-situation has been marked by the managers of guest accommodation enterprises whose companies have already been working for 1-5 years. The newly established business managers, in addition to the problem-situation solving, appreciate the employees' ability to make decisions. Employees' ability to orientate in the recreation resources and apply them, development and management of recreation routes and infrastructure projects, events and programmes have been assessed as partly necessary. $75 \%$ of business managers do not see any need for the staff changes in their enterprise right now. It means that, when planning development of their company's offer, the managers of guest accommodation enterprises do not consider the attraction of new specialists as the main precondition and primary issue to be solved.

\section{Conclusions}

The outcomes of the research confirm that basically the offer of recreation services in Kurzeme Region is provided by guest houses and holiday homes with 6 and more years of experience. Also, establishing new guest accommodation enterprises, mostly holiday homes are created, which still confirms the attraction of the business field in Kurzeme Region.

Regarding the recreation activities, in the offer of guest accommodation enterprises the clients are provided with walks and relaxation in nature. The offer of bath-house treatments and cycling to clients is more popular than SPA treatments and water attractions, as well as Nordic walking, boating and sports activities available in the companies regardless their length of experience in the field. It can be concluded that in Kurzeme Region the recreation offer complies with the away from home and relaxation tourism paradigms. The widest range of recreation offers and diverse SPA treatments is available in the guest accommodation enterprises that have been working for 11-15 years. Also, the companies started their guest accommodation business in the region during the last year, are trying to provide a variety in their recreation offer. 
Diāna LİDUMA, Ilze GROSPIN̦A, Zane GUSTA. Recreation offer and competences needed for its development in accommodation enterprises of Kurzeme region in Latvia

PROBLEMS

OF MANAGEMENT

IN THE $21^{\text {st }}$ CENTURY Vol. 12 , No. 2, 2017

134

The outcomes of the research confirm that the managers of guest accommodation enterprises in Kurzeme see the potential in the sports recreation events and relaxation activity organization.

As an insufficiency of the recreation offer in Kurzeme Region is seen the tendency nowadays that in half of the regional accommodation enterprises the organization of relaxation activities has to be provided by clients themselves. On the one hand, the client is free to choose the type of relaxation, but on the other hand - a professional opinion on the most suitable recreation types is not received, in compliance with the resources available at the tourism destination. A positive thing is the fact that $43.8 \%$ of the managers in Kurzeme Region accommodation dwellings do see the demand for management specialists in relaxation organization in future. $15.6 \%$ of companies would need a manager for relaxation organization right now. The outcomes of the research show that the main competences necessary for employees of guest accommodation enterprises from the business managers' point of view are knowledge of languages, ability to make decisions and solve problem-situations. Knowledge in marketing, public relations and project management field is topical.

In the research it has been found out that $65.6 \%$ of the surveyed business managers are planning development of a new relaxation offer, but $68.8 \%$ of managers in guest accommodation business are planning to invest in development of the current services. Taking into account that $75 \%$ of the business managers do not see a necessity for changes in the staff, it can be concluded that from the guest accommodation business managers' point of view attraction of new specialists for recreation and relaxation organization cannot be considered as the main precondition for the recreation offer's development in Kurzeme Region.

\section{References}

Bērziņa, K. (2008). Türisma un viesmīlìbas terminu skaidrojošā vārdnīca [Tourism and hospitality explanatory dictionary]. Rīga: LR EM.

Clawson, M., Knetsch J. L. (2011). Economic of outdoor recreation. USA: University of New Mexico.

CSP. (2017). Ārvalstu vairākdienu ceḷotāju ceḷojuma nolūks Latvijā sadalījumā pa valstīm (\%). [Destination of foreign multi-day travelers in Latvia by country (\%)]. Retrieved from: http://data.csb.gov.lv/ pxweb/lv/transp/transp__ikgad_turisms/TU0140.px/table/tableViewLayout2/?rxid=cdcb978c22b0-416a-aacc-aa650d3e2ce0.

CSP. (2017). Viesnīcas un citas tūristu mītnes Latvijas statistiskajos régionos, republikas pilsētās un novados [Hotels and other tourist accommodation in the statistical regions of Latvia, republican cities and counties]. Retrieved from: http://data.csb.gov.lv/pxweb/lv/transp/transp_ikgad_turisms/ TU0040.px/table/tableViewLayout2/?rxid=cdcb978c-22b0-416a-aacc-aa650d3e2ce0.

CSP. (2017). Tūrisma komersantu darbības raksturojošie rādītāji [Indicators characterizing the activities of tourism enterprises]. Retrieved from: http://data.csb.gov.lv/pxweb/lv/transp/transp_ikgad turisms/ TU0080.px/?rxid=cdcb978c-22b0-416a-aacc-aa650d3e2ce0.

Dadzis, M. (2017). Pašvald̄̄bas loma tūrisma uznēmējdarbības veicināšanā Ventspils novadā. [Municipality's role in tourism business promotion in Ventspils region]. Retrieved from: http://www.visitventspils.com/files/2017 042017 novads dadzis.pdf.

Kuldīgas novada dome. (2013). Kuld̄̄gas novada attīstības programma 2014. - 2020. gadam (1. redakcija). [Development Programme of Kuldīga Region for 2014-2020 ( $1^{\text {st }}$ edition)]. Retrieved from: http://www.kuldiga.lv/userfiles/files/Kuldigas novada AP 1redakcija.pdf.

Latvijas kūrortpilsētu asociācija. (2013). Projekta $\bar{N} R$. 3.2.1.1/16/A/010 "Latvijas veselības tūrisma klasteris" aktivitātes. [Project NR. 3.2.1.1/16/A/010 "Latvian Health Tourism Cluster" activities.]. Retrieved from: http://www.healthtravellatvia.lv/lv/projekta-nr-321116a010-latvijas-veselibas-turisma-klasteris-aktivitates.

Latvijas Republikas Saeima. (1999). Tūrisma likums [Tourism Law]. Retrieved from: https://likumi.lv/ doc.php?id $=50026$.

Liepājas pilsētas dome. (2015). Lēmums nr. 64 "Par Liepājas kūrorta attīstības koncepciju 2015 - 2020. gadam”. [Decision No 64 “About Development Concept of Liepāja's Resort for 2015-2020.”] Retrieved from: http://www.liepaja.lv/upload/kurorts/liepajas domes lemums 1902 2015.pdf.

McLean, D., Hurd, A. (2011). Recreation and leisure in Modern era. London: Jones and Bartlett. 
Diāna LİDUMA, Ilze GROSPIṆA, Zane GUSTA. Recreation offer and competences needed for its development in accommodation enterprises of Kurzeme region in Latvia

Ministru kabinets. (2017). MK noteikumi Nr. 264 "Noteikumi par Profesiju klasifikatoru, profesijai atbilstošiem pamatuzdevumiem un kvalifikācijas pamatprasībām”. [Regulations No 264 by the Cabinet of Ministers "Regulations about Profession Classification, appropriate principle tasks and basic requirements for the qualification"]. Retrieved from: https://likumi.lv/ta/id/291004-noteikumi-par-profesiju-klasifikatoru-profesijai-atbilstosiem-pamatuzdevumiem-un-kvalifikacijaspamatprasibam.

Online Etimology Dictionary. (2017). Recreation. Retrieved from: https://www.etymonline.com/ search?q=recreation

Pētersons, R., Plinta, E. (2002). Angḷı-latviešu tūrisma terminu skaidrojošā vārdnīca. [English-Latvian tourism explanatory dictionary]. Rīga: Daugava.

Tribe, J. (2012). The economics of recreation, leisure and tourisms. India: Press.1td.

Received: November 14, 2017

Accepted: December 25, 2017

\begin{tabular}{|l} 
PROBLEMS \\
OF MANAGEMENT \\
IN THE 21 $1^{\text {st }}$ CENTURY \\
Vol. 12, No. 2, 2017 \\
\hline 135
\end{tabular}

\begin{tabular}{|ll|}
\hline Diāna Līduma & $\begin{array}{l}\text { Mg.oec., lecturer, Liepaja University, Liepaja, LV-3401, Liela iela 14, Latvia. } \\
\text { E-mail: diana_liduma@inbox.Iv }\end{array}$ \\
\hline Ilze Grospina & $\begin{array}{l}\text { Mg.paed., Lecturer, Liepaja University, Liepaja, LV-3401, Liela iela 14, Latvia. } \\
\text { E-mail: diana_liduma@inbox.Iv }\end{array}$ \\
\hline Zane Gusta & $\begin{array}{l}\text { Bac.oec., Ovner, Zoovilla, Ltd., Grobina, LV-3430, "Mārsili", Latvia. } \\
\text { E-mail: z.timbra@googlemail.com }\end{array}$ \\
\hline
\end{tabular}

